\title{
CIF Letters/Lettres de I'IFC
}

November 14, 1985

Honourable Kenneth Streatch

Minister of Lands and Forests

Toronto Dominion Bank Building

1791 Barrington Street

P.O. Box 698

Halifax, N.S

B3J 2 T9

\section{Dear Mr. Streatch:}

The Canadian Institute of Forestry is Canada's national association of forestry professionals. It has some 2500 members and operates through 23 local sections located from Newfoundland to Vancouver Island. The current President is Mr. J.W. Toovey of Vancouver, B.C.

The Institute's objectives are:

- To improve all aspects of forestry in Canada.

- To foster public understanding of forestry, forests and forest industry including their role in the maintenance and improvement of environmental quality.

- To advance members in their knowledge of forestry.

- To publish a professional and technical forestry journal, The Forestry Chronicle.

- To cooperate with other organizations having similar objectives.

Through its head offices in Ottawa, the Institute pushes for improved forestry policies at the Federal level while the sections focus more on local and provincial forestry issues. Nova Scotia Section covers your Province. The current chairman is $\mathrm{Mr}$. Peter Jackson of Port Hawkesbury.

The CIF is not a registration or licensing body for the profession. As you know, this aspect of all professions comes under provincial jurisdication. At the present time, five provinces have legislation providing for the registration or licensing of professional foresters. There are British Columbia, Alberta, Ontario, Quebec and New Brunswick.

The professional foresters in Nova Scotia are most interested in seeing this type of legislation enacted there. The Canadian Institute of Forestry is strongly supportive of this concept. Such legislation should have as its principal raison d'être the protection of the public. Its enactment would help ensure that foresters in government, industry and private consulting practice are fully qualified and prepared to accept full responsibility for their work. This type of legislation is particularly germane in the case of the private consultant. Experience has shown that, with today's increasing emphasis on privatization and smaller government, the role of the professional forester consultant is increasing. Governments, industry and the public are relying on them more and this trend will accelerate.

The Canadian Institute of Forestry urges that you give favorable consideration to introducing legislation of this kind

R.J. Bourchier Executive Director Canadian Institute of Forestry

December 9, 1985

Mr. R.J. Bourchier

Executive Director

Canadian Institute of Forestry

\section{Dear Mr. Bourchier:}

During the last six weeks, I have received letters from various Registered Professional Forestry Associations from across Canada. I appreciate the interest of the provincial Associations and the Canadian Institute of Forestry in having legislation enacted in Nova Scotia allowing for the registration of its professional foresters.

I feel the time is appropriate to consider such an initiative, and will be meeting with those foresters in the province who have spearheaded the request over the past number of years.

Yours sincerely,

Ken Streatch Minister

N.S. Department of Lands and Forests

November 4, 1985

The Hon. John N. Turner

Office of the Leader

of the Opposition

House of Commons,

Ottawa, Canada

\section{Dear Mr. Turner:}

On Octiober 18-19th, the Sierra Club of Ontario sponsored a Forestry Conference - Woodstock. This was a National Conference focused on forestry, which brought together provincial and federal government agencies, industrial companies and associations, professional institutes, faculties of forestry, Christian churches, and several environmental groups. The Conference was well organized and there was definitely an open spirit of dialogue developed through the two days of meetings, workshops, and plenary sessions. The overall results were positive, and I believe that many of the organizations represented will go back to their respective provinces and take a broader perspective on the overall interface associated with forest management and conservation in general.

However, I regret to report that, in the closing minutes of the conference, your Environmental Critic, Mr. Charles Caccia presented some very misleading and negative comments on forest practices in British Columbia. To the best of my memory, his comments were:

"There is a crisis in public confidence. I say this because I have flown over British Columbia and have seen how

the forest industry gets away with murder, aided and abetted by a government that has the backbone of a jellyfish".

You know, based on your direct involvement with the forest industry in B.C., that these comments are unfounded and blatantly misleading. This type of emotional bias belongs in the House of Commons where "freedom of speech" has become accepted by the general public. It is not the type of comment professional foresters from across Canada would expect from a senior member of the Liberal Caucus, particularly a member with responsibility and accountability in the sector of environment and forestry. Foresters would have expected the Liberal Party representative at Woodshock to have contributed a more positive and constructive tone.

Yours very truly Jack W. Toovey President Canadian Institute of Forestry 
November 29, 1985

Jack W. Toovey

President

Canadian Institute of Forestry

Dear Mr. Toovey:

Thank you for your letter of November 4. 1985 regarding comments our critic for the Environment, Mr. Charles Caccia, made recently in British Columbia.

I wish to assure you that I do not agree with the thrust of Mr. Caccia's remarks as they were reported. I do not believe that the forestry industry in British Columbia has "gotten away with murder".

I do believe, however, that both the government of British Columbia and the Mulroney government have been lacking in real commitment and imagination in terms of their efforts to protect our forest resource.

In closing, I would like to reassert our commitment to the growth of your industry on behalf of all members of the Liberal Caucus. Mr. Caccia is a forester by training. His comments, while perhaps unduly negative, were well intentioned, and borne of his sincere desire to raise public consciousness about the vulnerability of our environmental heritage.

Again, thank you for bringing this important matter to my attention.

Sincerely, John N. Turner Leader of the Opposition
December 13,1985

Mr. Jack Toovey, President Canadian Institute of Forestry

\section{Dear Jack:}

On behalf of the Canadian Council of Forest Ministers, my co-host, the Honourable Kenneth $J$. Streatch and I wish to thank you for having participated in the Canadian Forestry Forum on Labour Market Issues in Halifax on November 20 and 21.

I realize that we could not have possibly explored all the questions centering on employment opportunities, human resour- ces planning and training, and labourmanagement relations in our sector. However, I believe that we made a significant start in identifying the nature of the challenges and opportunities. I look forward to discussing your advice on these important topics with my colleagues in the Canadian Council of Forest Ministers when we make our preparations for the National Forest Congress. I hope that the Forum was a useful undertaken for you as well.

A synthesis of the proceedings of the Forum is now being finalized that will incorporate the written statements prepared by your working groups and the subsequent discussions that took place during the plenary session. A copy of the proceedings along with a list of participants and a transcript of Dr. Tom McCormack's presentation will be sent to you shortly.

Thank you for having shared your knowledge and wisdom on this very important and complex set of issues with the Canadian Council of Forest Ministers.

Yours sincerely,

Gerald S. Merrithew

Minister of State

(Forestry)

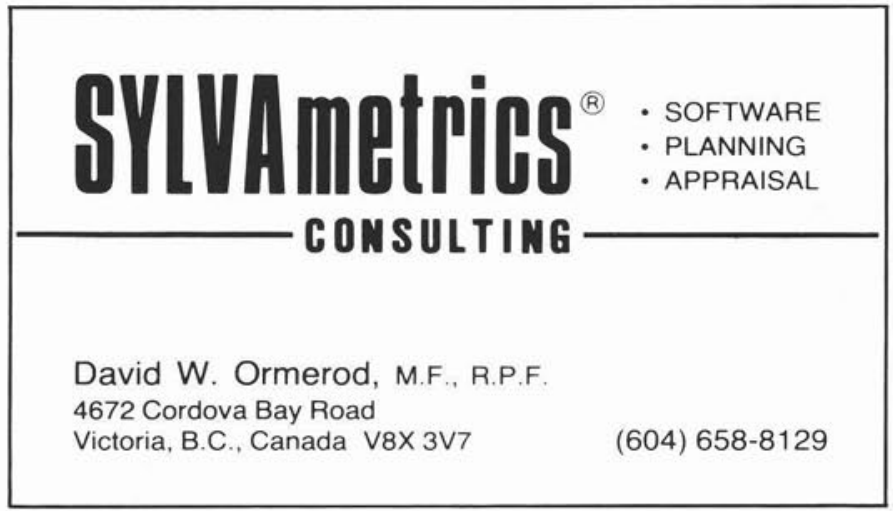


January, 1986

The Right Honourable Brian Mulroney

Prime Minister of Canada

House of Commons

Ottawa, Ontario

\section{Dear Mr. Mulroney:}

In July, 1984, as Leader of the Official opposition, you spoke at the conclusion of a two-day caucus meeting of western Conservative MPs and candidates in Prince Albert, Saskatchewan, of the PC's policy proposals on forestry and related industries. Among those proposals you stated the following:

"A PC Government will provide that leadership by appointing a Minister of Forestry. This would consolidate all Federal forestry-related programs under one Ministry. This action will eliminate waste and duplication, not create any new bureaucracy."

Although a Ministry of State for Forestry was formed after the Progressive Conservative Party took office in September. 1984, the Ministry does not speak for all those components which comprise the forestry sector. The industrial and marketing components of an all encompassing forestry ministry still remain with other federal agencies. Hence, the federal government has still not formed a Ministry which consolidates all federal forestryrelated programs proposed in July, 1984.
The Council, Central Ontario Section, Canadian Institute of Forestry, on behalf of its members, applauds the Prime Minister for the support and status that you and your cabinet colleagues have given federal forestry, particularly the Canadian Forestry Service, during the past year. However, it is our belief that your support of forestry at the federal level must move further towards the formation of a Department of Forestry which would include all those elements that you spoke of in Prince Albert. Only then can the federal government speak authoritatively from one source. The Central Ontario Section, Canadian Institute of Forestry, fully supports the government moving in this direction.

We believe that Canada's number one industry faces intense competition in both the short and long run from major competitors around the world who, like Canada, are seeking commodity markets in all four corners of the globe. Basic forest research and development and technology transfer must be strongly supported and adequately funded, marketing opportunities continually explored, closer ties with the industry encouraged, and Canada's reputation as a reliable supplier of high quality products advertised far and wide. These efforts must be carried out under one federal umbrella; namely a federal department of forestry.
We urge you to give serious consideration to this matter of a federal department of forestry. The Central Ontario Section and the Canadian Institute of Forestry strongly favours this proposal and will continue to encourage fellow members of the forestry community and others to lobby for this much needed requirement to consolidate federal agencies involved in forestry, thus establishing a focal point for forestry matters in Canada.

As you very appropriately put it in July, 1984

"With federal leadership and consulta-

tion, the federal sector can grow by

$40 \%$ in the next two decades."

We know that this can be achieved, but it requires your government to put the mechanism in place to make it happen.

Sincerely yours,

\section{Jack Smyth, Director \\ Harry Graham, Chairman \\ Art Groot, Vice Chairman \\ Gordon Stone \\ Edward Tear \\ C. Rod Smith \\ Barney Smith \\ Bob Currell \\ Richard Macnaughton}

Council, Central Ontario Section, Canadian Institute of Forestry

\section{FOREST MANAGEMENT}

\section{Natural Resources Management} Program

\section{Simon Fraser University}

Applications are invited for a tenure-track appointment at the Assistant Professor rank beginning 1 September 1986 subject to budgetary authorization. Areas of emphasis are forest management and policy with specialization in: silviculture or economics or soils and land capability in appointee will teach graduate courses, direct graduate research, and conduct personal research in a dynamic interdisciplinary program. A Ph.D. degree, practical experience, and eligibility for registration as a professional forester are desired. Preference will be given to at the time of application. Closing date: 1 March 1986 or until filled. Send curriculum vitae, transcripts, samples of relevant publications, and request three referees to send confidential letters of recommendation directly to:

$$
\text { Dr. J.C. Day }
$$

Natural Resources Management Program Simon Fraser University Burnaby, B.C. V5A 1 S6

$$
\text { Canada }
$$

\section{Position Announcement FOREST ENGINEERING UNIVERSITY OF ALBERTA}

The University of Alberta, Department of Forest Science, invites applications for a tenurable faculty position with appointment to tenurable faculty position with appointment to
be effective July 1,1986 or as soon thereafter as possible.

Candidates should have graduate training (Ph.D. preferred) in Forestry or Engineering and experience in the forest industry. Duties will include undergraduate and graduate teaching and research in the areas of forest harvesting and transportation.

The 1985-86 salary range for an assistant professor is $\$ 30,316$ to $\$ 43,780$. Applications, including a curriculum vitae and names and addresses of three referees, should be addresses of three referees,

Dr. James Beck, Chairman

Forest Science Department

Faculty of Agriculture and Forestry

817 General Services Building

University of Alberta

Edmonton, Alberta

Canada

T6J 0B9

The University of Alberta is an equal opportunity employer, but in accordance with Canadian immigration requirements, this advertisement is directed to Canadian citizens and permanent residents. 